\title{
Tourism Ethnocentrism and its Effects on Tourist and Resident Behavior
}

\author{
Kock, Florian; Josiassen, Alexander; Assaf, A. George; Karpen, Ingo; Farrelly, Francis
}

\author{
Document Version \\ Accepted author manuscript \\ Published in: \\ Journal of Travel Research \\ DOI: \\ $10.1177 / 0047287518755504$ \\ Publication date: \\ 2019 \\ License \\ Unspecified
}

Citation for published version (APA):

Kock, F., Josiassen, A., Assaf, A. G., Karpen, I., \& Farrelly, F. (2019). Tourism Ethnocentrism and its Effects on Tourist and Resident Behavior. Journal of Travel Research, 58(3), 427-439.

https://doi.org/10.1177/0047287518755504

Link to publication in CBS Research Portal

\section{General rights}

Copyright and moral rights for the publications made accessible in the public portal are retained by the authors and/or other copyright owners and it is a condition of accessing publications that users recognise and abide by the legal requirements associated with these rights.

\section{Take down policy}

If you believe that this document breaches copyright please contact us (research.lib@cbs.dk) providing details, and we will remove access to the work immediately and investigate your claim.

Download date: 26. Apr. 2023

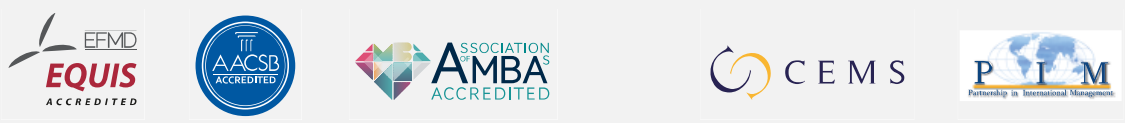




\title{
Tourism Ethnocentrism and its Effects on Tourist and Resident Behavior
}

\author{
Florian Kock, Alexander Josiassen, A. George Assaf, Ingo Karpen, and Francis Farrelly
}

Journal article (Accepted manuscript*)

\section{Please cite this article as:}

Kock, F., Josiassen, A., Assaf, A. G., Karpen, I., \& Farrelly, F. (2019). Tourism Ethnocentrism and its Effects on Tourist and Resident Behavior. Journal of Travel Research, 58(3), 427-439. 001: 10.1177/0047287518755504

\section{DOl: https://doi.org/10.1177/0047287518755504}

Copyright (C) The Author(s) २०18. Reprinted by permission of SAGE Publications.

* This version of the article has been accepted for publication and undergone full peer review but has not been through the copyediting, typesetting, pagination and proofreading process, which may lead to differences between this version and the publisher's final version AKA Version of Record.

Uploaded to CBS Research Portal: July २०19 


\section{Tourism Ethnocentrism and its Effects on Tourist and}

\section{Resident Behavior}

Florian Kock ${ }^{1,2}$ corresponding author

Doctoral Candidate

${ }^{1}$ Copenhagen Business School, Department of Marketing, Solbjerg Plads 3, 2000

Frederiksberg, Denmark

${ }^{2}$ Royal Melbourne Institute of Technology, 379-405 Russell Street, 3000 Melbourne VIC, Australia

fk.marktg@cbs.dk

$+4538152126$

Alexander Josiassen ${ }^{1}$

Professor

aj.marktg@cbs.dk

$+4538152159$

A. George Assaf ${ }^{3}$

Associate Professor

${ }^{3}$ Isenberg School of Management, University of Massachusetts Amherst, Flint Lab 209A, 121

Presidents Drive Amherst, MA 01003, United States of America

$\underline{\text { assaf@isenberg.umass.edu }}$

$+14135451492$

Ingo Karpen ${ }^{1,2}$

Associate Professor

ingo.karpen@rmit.edu.au

+61399255877

Francis Farrelly ${ }^{2}$

Professor 


\title{
francis.farrelly@rmit.edu.au
}

\section{$+61399251475$}

Final version published as: Florian Kock; Alexander Josiassen; A. George Assaf; Ingo Karpen; Francis Farrelly / Tourism Ethnocentrism and its Effects on Tourist and Resident Behavior. Journal of Travel Research, Vol. 58, No. 3, 2019, p. 427-439

\begin{abstract}
People often demonstrate a home country bias toward their own nation over other nations. This bias is an important determinant of their behavior. Drawing on seminal research from marketing and psychology, the authors provide the first investigation of the tourism ethnocentrism (TE) phenomenon which captures tourists' and residents' motivation to support the domestic tourism economy. The research reported herein develops the parsimonious, reliable and valid TE scale, and provides an empirical test thereof. The results show that TE is an important means to investigate both tourists' and residents' behavior. It drives tourists' willingness to engage in and recommend domestic tourism, as well as residents' support for domestic tourism development. The results further reveal that higher levels of tourists' "perceived self-efficacy to contribute to the domestic economy" and lower levels of “perceived economy support of others" strengthen TE's effect. The authors discuss the implications of these findings for research and practice.
\end{abstract}

Keywords: tourism ethnocentrism, home country bias, tourist behavior, tourist psychology 


\section{Introduction}

Recent years have witnessed a rise in patriotic tendencies the world over (The Economist 2016). The central tenet is that the home country should take precedence above all else and be supported by those who associate with it. This reinvigorated ethnocentrism is evidenced by recent social and political developments. For example, Britain's exit from the European Union ('Brexit') was fueled by a wish to refocus on national instead of European interests. Similarly the American election was defined by the credos 'America First' and 'Make America Great Again' (The Economist 2017). These recent developments reflect the deep resonance of ethnocentrism in public consciousness, and people's need to orient themselves in a globalized world. While the important implications of this development are extensively discussed in the media and by political academics, there has been little mention, let alone investigation, of the potential effects of this home country bias on tourist and resident behavior. If ethnocentrism can lead to political upheaval and divisions in society, it is feasible that it may also impact tourist intent to spend the holiday in their home country rather than in a foreign country.

An important vehicle through which people can express a home country bias is their consumption preferences (Josiassen 2011; Verlegh 2007). Indications of this phenomenon can be found in the 'Made in Australia' (started in 1986) or the recently reemphasized 'Buy American' campaign, through which ethnocentric consumption motives are triggered. Accordingly, individuals who strongly associate with their home country may prefer domestic consumption options in order to economically support their home country and its inhabitants. We suggest that ethnocentric predispositions also exist in the tourism domain, among both tourists and residents, and shape their predispositions and behavior. The 'See America First' campaign by the Great Northern Railway to boost tourism to America's National Parks in the early 1900's can be seen as one of the earliest manifestations of ethnocentrism in tourism. 
This campaign targeted the American upper-middle class who took lengthy trips to Europe. We suggest that ethnocentric predispositions still exist among both tourists and residents and that they continue to shape attitudes and behaviors in the tourism domain.

This study introduces and provides an initial empirical investigation of the tourism ethnocentrism (TE) phenomenon, which is defined as an individual's prescriptive beliefs and felt moral obligation to support the domestic tourism economy. TE is conceptually and empirically different from destination image; while destination image captures tourists' beliefs about the quality and features of a destination, the home country bias TE reflects individuals' prescriptive beliefs related to supporting the domestic tourism industry. The label 'bias' implies that the predisposition is unjustifiable in the sense that it goes beyond objective quality criteria. In this way, the present study contributes to the literature on tourist behavior and mental destination representations (e.g. destination image and destination imagery: Baloglu et al. 1999; Josiassen, Assaf, Woo and Kock 2016; Kock, Josiassen and Assaf 2016) by outlining a second important pathway through which a destination cue can affect tourists' preferences. Importantly, while the research area of intergroup bias has attracted significant attention from social psychology researchers who aim to understand human behavior for decades (e.g. Allport 1954; Brewer 1999; Hewstone, Rubin and Willis 2002), the literature on tourist and resident behavior remains almost completely uninformed by these theories. By supplementing our understanding of tourist and resident behavior through the lens of intergroup bias, we reiterate Pearce and Stringer's (1991) important contention that tourism is essentially a social psychological phenomenon in which "people's tourism behavior will derive from primary or secondary groups to which they belong" (p. 147). 


\section{Introducing Tourism Ethnocentrism}

Due to globalization and lower travel costs in particular, the tourism industry is becoming increasingly global and offers tourists more destination and price point options than ever before. Increased globalization opens up new opportunities for tourism managers to enter international markets, while at the same time resulting in increased pressure from international competitors entering domestic markets. Traditionally, both tourism managers and academics have used established, yet powerful marketing approaches to understand tourist behavior and decision-making. Most of these approaches, such as destination image, rest on the intuitive notion that tourists select a destination because of objective quality and value considerations. These approaches follow the seminal assumption that individuals aim to maximize their utility by choosing an option that best meets their individual travel and vacation needs (e.g. Kock, Josiassen and Assaf 2016; Prayag and Ryan 2012). Importantly, studies have also comprehensively documented that tourists select destinations for their symbolic meaning, examining seminal constructs such as destination self-congruity (Sirgy and Su 2000), destination personality (Ekinci and Hosany 2006) or a destination's social return on social media (Boley, Jordan, Kline and Knollenberg 2018). Extending research on a destination's symbolic meaning and seminal social psychological accounts, we suggest that tourists may not always use quality or value considerations for decision-making but rather can be guided by a group-based bias that goes beyond such considerations.

When people allocate resources (e.g. money, power, knowledge, attention) among other individuals, they often base their choice on defining characteristics of potential recipients. One of the most important and salient characteristic of the recipient is his or her groupmembership. Social psychologists have investigated intergroup behavior and intergroup biases extensively (e.g. Balliet, Wu and De Dreu 2014; Brewer 1999; Hewstone et al. 2002; Tajfel 1982) to understand various political and social phenomena that have severe 
consequences for societies. Intergroup bias is a general yet not universal phenomenon in which social psychology differentiates between in-group bias and out-group bias (Buttelmann and Böhm 2014; Brewer 1999). In particular, intergroup biases can take the form of favoring the in-group (i.e. positive in-group bias) or derogating an out-group (i.e. negative out-group bias). Importantly, in-group attraction and out-group derogation are not reciprocally related, and people can strongly favor the in-group without necessarily holding a negative attitude toward out-groups (Brewer 1999).

As early as 1954, the famous social psychologist Gordon Allport postulated in his book 'The Nature of Prejudice' in the chapter 'Ingroup Formation' that in-group members are 'psychologically primary' in the sense that individuals who belong to the same group are prone to favor and help each other. From an evolutionary perspective, environmental challenges from our past have propelled ancestral humans toward life in highly interdependent and cooperative groups (Schaller and Neuberg 2008). The formation and demarcation of groups based on race, religion or nationality, among others, is therefore a crucial survival-relevant mechanism that offers the individual resources (benefits) in exchange for other resources (costs). As such, an in-group bias that favors the in-group does not exist for its own sake but serves an instrumental function for group members that engage in mutual cooperation and mutual obligation (Scheepers, Spears, Doosje and Manstead 2006). The instrumental function of in-group bias is context-dependent and may manifest in various situations and even among children (Buttelmann and Böhm 2014). For example, in the seminal study that became known as the Robbers Cave Experiment, Sherif and Sherif (1953) document an in-group bias of resource allocation between two groups of boys in a summer camp.

Ethnocentrism is a positive in-group bias that reflects the systematic favoritism of the home nation or its members over other nations (Sumner 1908). We suggest that both domestic 
tourists and residents may harbor such a systematic in-group bias that manifests in the prescriptive belief, and felt moral obligation, that the domestic tourism economy should be supported. For ethnocentric tourists, spending a holiday at a domestic destination is socially expected and a way to secure domestic jobs. For ethnocentric residents, supporting domestic tourism development is another, yet indirect, way to do so. Thirty years ago, marketing research introduced the concept of consumer ethnocentrism which "captures the beliefs held by consumers about the appropriateness and indeed morality of purchasing foreign-made products" (Shimp and Sharma, 1987, p. 280). Ethnocentric consumers believe that imports should be taxed heavily, and only very little trading should occur between countries in an effort to decrease the harmful impact of imported products on the domestic economy.

While TE is a positive instrumental in-group bias that is specifically concerned with the domestic tourism economy and its stakeholders, the original definition of consumer ethnocentrism includes a degree of contempt toward products from other countries and gives the individual a sense of identity and feelings of belongingness (Shimp and Sharma 1987). Further, consumer ethnocentrism focuses on the competition between domestic and foreign products and reflects consumers' concerns with the harmful effect of imports on the domestic economy. Consumer ethnocentrism is thus not appropriate to investigate tourists' active preferences for domestic destinations. In contrast and line with recent research on in-group biases from social psychology (Lowery, Unzueta, Knowles and Goff 2006; Hammond and Axelrod 2006) and marketing (Josiassen 2011), TE reflects the active support of the in-group in the tourism context and hence suits the purpose of this study.

In order to uncover the nature and existence of this phenomenon, we first conducted 17 interviews in the US through a street intercept. Informants were asked about their next holiday destination and, given that the US was mentioned, asked for their motives to take a 
domestic holiday. Exemplary statements that indicate the existence of a TE bias are shown in Table 1.

-- Insert Table 1 about here --

The initial interviews provide exploratory indication of the existence of TE and show signs of its potential to influence destination choice. Specifically, ethnocentric tourists and residents 1) distinguish between 'us' and 'them', 2) understand their travel behavior as a means to support the domestic country, and 3) feel obliged to help fellow citizens who work in and depend on the domestic tourism economy. Further, the interviews indicate that ethnocentric tourists do not evaluate domestic destinations on their own merits (i.e. based on quality considerations and features) and may even go as far as paying a higher price for a domestic destination that is comparable to a foreign one. From the perspective of ethnocentric tourists, booking a domestic holiday is a patriotic duty that keeps jobs in the US and benefits the economy, thus qualifying for an instrumental in-group bias that is functional in itself (Scheepers et al. 2006). Importantly, ethnocentric tourists internalize solidarity with the domestic tourism economy and call for conformity and cooperation from other in-group members, thereby echoing social psychologists' conceptualization of mutual cooperation and obligation of in-group behavior (Brewer 1999). 


\section{Conceptual Framework and Hypotheses}

Existing research documents that ethnocentric tendencies do not exist for their own sake but are functional in the sense they motivate individuals to act in line with them. This study sets out to provide an initial test of TE and whether it matters in predicting tourists' and residents' predispositions and behavioral intentions toward domestic tourism. We refer to these predispositions and behavioral intentions as tourism related outcomes (TRO). As TE reflects prescriptive beliefs to support the domestic tourism economy, it is likely that individuals endorse these beliefs in their roles both as tourists and as residents. Our framework is anchored in seminal psychological accounts of attitude theory (Ajzen 2001; Heider 1958), suggesting that individuals seek consistency between their predispositions and their behavior. Drawing on the incidents from our interviews as well as related marketing literature (Josiassen 2011; Klein, Ettenson and Morris 1998), we suggest that ethnocentric tourists, who believe that the domestic tourist economy should be supported, have a higher willingness to spend their own holiday at a domestic destination. This contention is in line with various studies in which marketing researchers found that consumer ethnocentrism is a prevalent and important motive for consumers to buy domestic products instead of imports (e.g. Josiassen, Assaf and Karpen 2011; Shankarmahesh 2006; Verlegh 2007). Importantly, TE reflects a focus on the interests of the own country and does not necessarily extend to explicit negative attitudes and behaviors toward other countries. This perspective mirrors the distinction between patriotism and nationalism: One can be particularly devoted to the own country without harboring negative predispositions toward foreign countries (e.g., Brewer 1999). As such, explicitly negative attitudes are not systematically linked to TE but may result from other, negative out-group biases that go beyond the scope of this research. We selected willingness to engage in domestic tourism as a behavioral outcome because of its wide use in 
tourism research and its relevance for both tourism academics and managers. We thus put forward the following hypothesis for testing:

H1: TE has a positive effect on tourists' willingness to engage in domestic tourism.

Implicit to an instrumental bias is that its effectiveness depends on the mutual cooperation and solidarity of fellow in-group members. Thus, whether TE proves to be effective also depends on whether it is visible and motivational to other in-group members (Scheepers et al. 2006). Accordingly, ethnocentric tourists are interested in convincing others, leading us to suggest that TE has consequences in an intra-group communication context. This communication may manifest in tourists' inclination to provide positive word-of-mouth (WOM) about taking a domestic holiday. WOM is an important variable both for tourism and marketing researchers, and consumers engage in it for functional benefits (Lovett, Peres and Shachar 2013). In the case of TE, WOM sheds light on the process by which TE can spill over to other, nonethnocentric individuals, thus increasing its effect on tourist behavior.

H2: TE has a positive effect on positive word of mouth about domestic tourism.

In addition to investigating TE's influence on tourists' behavioral intentions, a second important and highly relevant research stream has examined residents' predispositions toward tourism in their home country (e.g. Rasoolimanesh, Roldán, Jaafar and Ramayah 2017; Vargas-Sanchez, Porras-Bueno and Plaza-Mejia 2011). Investigating residents' perceptions of tourism is important because understanding what causes residents to support or oppose domestic tourism is crucial for tourism industry's growth and success. We contend that TE does not only matter in coloring individual's perceptions in their role as tourists, but may also drive their predispositions toward domestic tourism in their role as residents. As such, TE may play an important role in shaping attitudes toward domestic tourism for both tourists and residents. 
Conceptually, we separate residents' attitudes toward tourism into a) residents' predispositions toward tourism development and b) residents' predispositions toward incoming tourists as individuals. Predispositions toward tourism development refer to residents' perceptions about benefits and costs from tourism and are therefore anchored in social exchange theory (Andereck, Valentine, Knopf and Vogt 2005; Perdue, Long and Allen 1990; Woo, Kim and Uysal 2015). In contrast, residents' predispositions toward incoming tourists refer to their perceptions of tourists as individuals and therefore reflect a relationship between residents and tourists (Woosnam, Norman and Ying 2009). Accordingly, the latter predispositions may be more meaningfully captured by socio-psychological accounts of intergroup behavior (Hewstone et al. 2002). Importantly, existing research is not clear on whether these two manifestations of tourism support are positively (Vargas-Sanchez et al. 2011), negatively (Teye, Sönmez and Sirakaya 2002), or not related. Residents may endorse governmental tourism development for functional cost-benefit reasons, independent of their predispositions toward individual tourists. The following hypotheses seek to shed light on this issue.

We put forward that ethnocentric tourists are likely also ethnocentric residents, and thus motivated to support the domestic tourism economy. As such, and in addition to their active contribution in their role as tourists (i.e. visiting and recommending domestic destinations), they are also likely to support tourism development in their home country in their role as residents. While existing research has identified several reasons that determine residents' support for tourism (Sharpley 2014 for a comprehensive overview), we believe that TE is another important intrinsic variable that can explain support for domestic tourism development. We put forward that ethnocentric residents have a higher propensity to support tourism development and therefore hypothesize:

H3: TE has a positive effect on residents' support for domestic tourism development. 
In addition to residents' support for tourism development, we identify another related yet fundamentally distinct manifestation of residents' attitudes: residents' hospitality toward tourists. In contrast to support for tourism development, hospitality implies that the resident directly interacts with incoming tourists, thereby constituting a different level of commitment. While residents' support for tourism development is extensively studied, residents' hospitality toward tourists has attracted only limited research. This is surprising because residents' hospitality is considered a key success factor in destination management (e.g. Wilson, Fesenmaier, Fesenmaier and Es 2001). We aim to add to this literature stream and put forward that ethnocentric residents are more hospitable toward incoming tourists than less ethnocentric residents because this behavior is beneficial for the domestic tourism economy. We hypothesize:

H4: TE has a positive effect on residents' hospitality toward incoming tourists.

Important implications for managers and academics may also be derived from insights that explain under which conditions TE affects tourists' and residents' TRO. We postulate that there may be benefits of TE for the domestic economy but that there may also be costs for the ethnocentric tourists and residents themselves, such as higher prices and diminished destination choice. In response to such considerations, ethnocentric tourists may ponder whether their individual contribution to the domestic tourist economy will play a significant role in advancing the collective goal. Specifically, tourists may hold counterarguments that their individual contribution is too small to make any difference (John and Klein 2003) and thus be less likely to translate their opinion into action. Such arguments are analogous in structure to arguments that one's individual vote will not change the result of an election, overall resulting in increased non-voting propensity. Applied to the tourism context, we suggest testing, as a contingency variable, the construct of perceived tourist self-efficacy, reflecting the level an individual perceives his or her travel behavior will impact a certain 
outcome. In this study, we put forward that an individual's beliefs in the impact on his own travel behavior on the tourism economy interacts with TE to predict willingness to engage in domestic tourism. Because perceived self-efficacy refers to the own travel behavior only, no interaction effects shall be present for the three other TRO. We suggest:

H5: Perceived tourist self-efficacy moderates the relationship between TE and willingness to engage in domestic tourism. The higher the perceived self-efficacy, the stronger is the relationship between TE and willingness to engage in domestic tourism.

Further, individuals may also hold beliefs that others already contribute to the domestic economy. We suggest that the more an individual perceives that fellow citizens are helping the domestic economy, the less important they consider their own contribution to the cause. As such, the effect of TE on tourism related outcomes (TRO) may be weakened when an individual intends to free ride on the ethnocentric behavior of others. Supporting this argument is the view that the probability that an individual will act is drastically reduced when other individuals are believed to be supporting the cause (e.g. Latane and Nida 1981). That is, ethnocentric tourists who believe that other tourists are already helping the domestic economy by spending their holiday at home are less likely to do the same. We hypothesize:

H6: Perceived support of fellow residents moderates the relationship between TE and TRO. The stronger the perceived support of fellow tourists, the weaker is the relationship between TE and TRO.

The TE scale and the developed hypotheses are now examined in two consecutive studies. In Study 1, in line with established scale development procedures (Churchill 1979; Homburg, Schwemmle and Kuehnl 2015), we develop the TE scale through the use of 21 structured interviews. This item-generation procedure is followed by a multi-step statistical analysis. Then, in Study 2 the developed hypotheses are tested in a nomological network; we examine 
whether TE matters for tourist and resident behavior, as well as the conditions under which it operates. Also in Study 2, we examine the predictive validity of TE vis-a-vis destination imagery, the construct which has most frequently been applied in the literature to explain tourist behavior (e.g. Baloglu and McCleary 1999; Josiassen, Assaf, Woo and Kock 2016). Further, we also empirically test the difference between TE and the consumer ethnocentrism construct. 


\section{Study 1: Scale Development}

Developing a tourism ethnocentrism scale is necessary for three reasons. First, the thirty-year old consumer ethnocentrism scale (CETSCALE) focuses on the harmful competition between imported and domestic products (Shimp and Sharma 1987). This threat of imported products is not realistic in a tourism context as destinations abroad cannot 'be imported' but tourists would actively travel to them. Items of the CETSCALE cannot be meaningfully adapted to the tourism context. For example, CETSCALE statements such as "imported products should be heavily taxed" or "only those products that are unavailable in the home country should be imported" are not applicable. Second, the existing CETSCALE is not consistent on whether it reflects a negative out-group bias or a positive in-group bias. However, this difference is important and the TE scale refers to an active support of the domestic destination, not active hostility toward foreign tourism entities. A third reason is that the CETSCALE does not address the complexities of existing consumer markets: Consumers may prefer foreign brands over domestic ones and still hold ethnocentric motives. For example, a BMW SUV is always built in the US while an Apple iPhone is always built in China. In tourism however, economic benefits are more direct and obvious because a tourism service is created at the destination (hotel, restaurant etc.). As such, we expect TE to represent a much clearer guiding principle for individuals than consumer ethnocentrism when making tourism-related decisions.

We generated an initial item pool for TE through a deductive qualitative analysis (Gilgun 2005), conducting interviews with 21 individuals. We recruited potential respondents through a street-intercept procedure in a mid-sized city in the Midwest of the U.S. In 2016, the U.S. were the biggest outbound tourism country by tourists, the second biggest by international tourism expenditure, and also the biggest in international tourism receipts (UNWTO 2017), thereby constituting an appropriate context for this research. We asked them to fill out a brief screening questionnaire that contained items reflecting a generic measure of patriotism (five 
items). We determined the respondents' patriotism levels (average or above-average) according to a cutoff of 4 out of 7 (Ouellet 2007). This cutoff point was the result of a pretest of the scale, which indicated a median of approximately 4. Interviews were conducted with the 21 informants that qualified and agreed to take part in the interview. In order to elicit mental content of TE, we asked respondents to describe beliefs and opinions relating to engaging in domestic tourism. This procedure, together with the initial indications from the first 17 interviews, yielded 43 items.

We then eliminated duplicate items from the interviews to avoid item redundancy. Further, we ensured satisfactory levels of content and face validity by asking four researchers with knowledge of the area to evaluate the items with regard to how well they reflected the full content of the TE construct. As a result of these two steps, we eliminated 33 items, leaving 10 items. In order to further reduce the number of items and empirically test their convergent validity, we distributed questionnaires containing these items, behavioral intention variables and several classificatory questions to a sample of U.S. respondents recruited from the Mechanical Turk online panel. One screener question ('Please select agree as answer here'; similar answer pattern as the other variables) was interspersed throughout the questionnaire and respondents who provided a wrong answer to it, thereby indicating a lack of attention, were deleted from the sample. We obtained completed questionnaires from 250 respondents. We conducted an initial exploratory factor analysis, which met both the Kaiser-Meyer-Olkin and Bartlett's test of sphericity, on the full sample. We evaluated all items consecutively using four criteria. First, we scrutinized factor loadings and item-to-total correlations sequentially, using .4 and .5 as the critical thresholds (Hair, Anderson, Tatham and Black 1998). Second, high inter-item correlations indicated item redundancy, therefore suggesting that we could drop one item while maintaining reliability. Third, for each item, we checked whether its deletion would increase scale reliability. We used composite reliability instead of 
Cronbach alpha because the latter is sensitive to the number of used scale items. Fourth, we used an iterated $\chi^{2}$-difference test procedure by selecting the item with the lowest item-tototal correlation, stopping only when the $\chi^{2}$-difference test indicated no difference or the adjusted goodness-of-fit index did not increase (Voss, Spangenberg and Grohmann 2003). These four item-reduction steps resulted in the removal of four items, leaving six items in the final TE scale. While a fifth item could have been deleted based on the steps above, we decided to retain it for reasons of construct validity (Peter 1981). Factor loadings of the six items ranged from .73 to .91 and the explained variation of the extracted factor was .68 . The composite reliability (CR) is .94 and the average variance extracted (AVE) is .74, thereby documenting reliability of the scale. The six items, their parameters, as well as scale parameters are shown in Table 2:

-- Insert Table 2 about here -- 


\section{Study 2: Hypotheses Testing}

The objective of Study 2 is to investigate whether TE matters and can reliably predict tourist and resident behavior. Specifically, in this study, the hypotheses are tested in the nomological network (Figure 1) with regard to structural relationships. In addition, we also provide an adhoc test to show that TE and CETSCALE perform differently in order to demonstrate the value of the TE scale for the tourism context.

\section{Participants and procedures}

Similar to Study 1, we obtained the data for Study 2 through questionnaires administered to a sample of U.S. respondents recruited from the Mechanical Turk online panel. Surveys administered through online panels are common in tourism research, providing reliable data while diminishing response bias (Boley et al. 2018). As initial classificatory questions, we asked respondents for their age, gender, income level and travel behavior. Only respondents that were 18 or older, that had sufficient funds to travel (household income of more than $30.000 \$$ ) and have travelled significant distances before (more than 70 miles in the last two years) were invited to answer the questionnaire. We collected 413 completed questionnaires. Since the research may tap into socially sensitive areas, we ensured respondents of anonymity and additionally included a social desirability scale to test for respondents' potential tendency to provide socially desirable answers (Crowne and Marlowe 1960). We also tested for common method bias through a marker variable and found that it does not distort our statistical analysis.

\section{Measures}

Table 3 provides an overview of all reflective scales used in the questionnaire as well as their respective items and psychometric parameters. The questionnaire contained the newly developed TE scale $(\mathrm{M}=3.89 ; \mathrm{SD}=1.39)$ as well as scales that measure the concepts 
involved in the nomological network to be tested. We measured tourists' willingness to engage in domestic tourism by adapting willingness to visit (WTV), as well as positive wordof-mouth (WOM) from Kock, Josiassen and Assaf (2016). In order to measure residents' hospitality $(\mathrm{RH})$ toward tourists, we developed a new scale by drawing on existing conceptualizations of hotel industry hospitality (e.g., Ariffin 2013). Residents'support for tourism (RST) was adapted from existing studies on perceptions on tourism development (Boley and Strzelecka 2016; Stylidis, Biran, Sit and Szivas 2014; Woo et al. 2015). Perceived tourist self-efficacy (TSE) and perceived support of fellow tourists (SFT) was adapted from Klein, Smith and John's (2004) measure of counter-arguments, and CE was captured by the CETSCALE (Shimp and Sharma 1987).

For all reflective multi-item scales convergent validity was achieved as standardized factor loadings were significant and above .7 for all items but one (.68), which was retained for ensuring construct validity (Bagozzi \& Yi, 1988). Average variance extracted (AVE) was above .5 for all constructs, further indicating convergent validity. Composite reliabilities were above .8 , thereby documenting adequate levels of reliability. An initial indication of discriminant validity among all scales, including TE and the CETSCALE, was obtained through the Fornell-Larcker (1981) criterion. For all pairs of scales, the AVE was higher than the pairwise squared estimated correlation, thereby indicating discriminant validity. We also applied the heterotrait-monotrait (HTMT) ratio criterion which measures the ratio of the average of the heterotrait-heteromethod correlations to the average of the monotraitheteromethod correlations (Henseler, Ringle and Sarstedt 2015). In all cases, the ratio was below .85, thereby further indicating discriminant validity (Kline 2011). In addition, we found all variance inflation factors to be below three, and therefore clearly below the critical threshold of 10 , indicating that collinearity was not harmful. 
Finally, we measured the formative destination imagery (DY) index by applying the association-strength-valence (ASV) method outlined by Kock et al. (2016). Through 12 interviews, conducted in the U.S. in the same region as the interviews for the TE scale development, we collected a list of 10 destination-specific and salient associations that individuals link to the tourist destination USA. Association strength is measured on a Likert scale ranging from not at all (0) to very much (6), and association valence on a Likert scale ranging from very negative (-3) to very positive (3). For each respondent, a formative ASV index was then calculated across all association strength-valence combinations (Kock et al. 2016). Variance inflation factors for all formative indicators are below the threshold of 3.3, thereby indicating that no harmful multicollinearity exists (Petter, Straub and Rai 2007).

\section{Results}

In a preliminary step, we examined the univariate skewness and kurtosis of the variables and found them to be within acceptable limits. The analysis of the social desirability scale indicated that social desirability bias was not present in the sample. Then, the hypothesized nomological network (Figure 1) was tested using a covariance-based structural equation modelling approach, using AMOS 24. The collected data fits the proposed model well, as indicated by the confirmatory factor analysis $\left(\chi^{2} / \mathrm{df}=3,069\right.$; confirmatory fit index $[\mathrm{CFI}]=$ .944 ; non-normed fit index $[\mathrm{NNFI}]=.934$; root mean squared error of approximation $[\mathrm{RMSEA}]=.071 ;$ standardized root mean residual $[\mathrm{SRMR}]=.0887)$

\section{-- Insert Figure 1 about here --}

Overall, we found strong support for the contention that TE plays an important role in understanding tourist and resident decision-making and behavior. TE has a significant and strong positive effect on both willingness to visit (WTV; .32, p <.001) and recommend (WOM; .45, $\mathrm{p}<.001$ ) the U.S. as a tourist destination, thereby confirming H1 and H2. In 
addition, higher levels of TE relate to higher levels of residents' support for tourism development (RST; .31, $\mathrm{p}<.001$ ), in full support of H3. However, we did not find a significant effect of TE on residents' hospitality toward tourists (RH; -.02, n.s.), thus rejecting H4. Importantly, purposefully these results corresponding to $\mathrm{H} 1$ to $\mathrm{H} 4$ have been obtained in the presence of DY, documenting that TE has explanatory power above and beyond DY. It is also worth noting that DY maintained significant links with all four outcome variables, and had a correlation with TE of only .18.

In the next step, we tested H5 and H6, and investigated two contingency factors that may interact with the effect TE has on TRO (i.e. H1 to H4). For H5, we hypothesized that higher perceived self-efficacy will strengthen the effect TE has on WTV, but has no effect on the remaining TRO variables. For H6, we put forward that if other residents are perceived to help the cause already (referred to as perceived support of others), the effect of TE on all TRO variables will be weaker. In an initial investigation, we conducted a median sample split for both moderators and analyzed the effects of TE on the four outcome variables in the four structural models. Because of the hypotheses' focus on the effect of TE on outcomes, DY was dropped from the model. As indicated in Table 4, the effects of TE on these outcome variables vary between low and high levels of the two moderation variables. In order to investigate whether these effect differences are significant between models, we conducted a multi-group analysis. We ran $\chi^{2}$-square difference tests between the two freely estimated models, only constraining one path at a time. As hypothesized for perceived self-efficacy, the difference between the two models is significant $(p<.05)$ for the effect TE has on WTV, but not for WOM, RST and RH. These results document that the effect of TE on WTV is significantly stronger if tourists believe that their own travel behavior can make a difference, thereby fully confirming H5. For perceived support of others, the interaction effect is significant for the relationships between TE and all four outcome variables; specifically for 
WTV $(\mathrm{p}<.05)$, WOM $(\mathrm{p}<.10)$, RST $(\mathrm{p}<.05)$ and RH $(\mathrm{p}<.05)$. In line with existing research using the same method (e.g., Walsh, Evanschitzky and Wunderlich 2007), we refer to the interaction effect on WOM as moderately significant. The results thereby confirm H6.

$$
\text { -- Insert Table } 4 \text { about here -- }
$$

In an ad-hoc test, we want to demonstrate that TE is a more appropriate measure to understand tourists' and residents' predispositions than the CETSCALE; we ran a model that included both measures, as well as all four TRO (WTV, WOM, RST and RH). We found discriminant validity for TE and the CETSCALE, and that TE had a strong and positive effect on willingness to visit $(.47, \mathrm{p}<.001)$ while the CETSCALE had no significant effect $(.11$, n.s.). This result documents that TE is an important instrument to understand tourists' travel intentions while the CETSCALE is not appropriate for this purpose.

In a last step, we want to address the need of tourism researchers and tourism practice for an ever shorter scale (i.e. when TE is not the main focus of the study). Applying even stricter statistical (i.e. inter-item correlations) and item redundancy criteria (i.e. comparable item wording), we deleted item 3 and item 5 from the scale and then ran all tests and models again. The properties of the measurement and structural model perform similarly well compared to the original scale, thus indicating that the resulting four item TE scale is an appropriate alternative for studies where TE is not the focal construct. Overall, we advocate adopting the full 6-item TE scale when possible, but this shorter version of the scale is provided for situations when questionnaire length is a concern.

\section{Discussion of the results}

The aim of this article is to introduce ethnocentrism to the study of tourism. The results show that the newly developed TE construct provides a new and important means to understand and investigate both tourists' and residents' predispositions and behavior. The TE scale is 
parsimonious, reliable, valid, and complements the destination imagery scale to understand and predict individuals' tourism-related predispositions. Specifically, TE has a positive effect on tourists' intentions to engage in domestic tourism and to recommend it to others. In addition, taking a resident's perspective, TE drives residents' support of tourism development, a key attitudinal factor in tourism research and management (Boley and Strzelecka 2016). While TE relates positively to WTV, WOM and RST, no effect was found on RH. The reason for this result could be that being hospitable to visitors goes beyond only helping the domestic economy by visiting, recommending and supporting it. Residents would have to also actively promote the interests of the out-group (incoming tourists). Although the end goal is still in the interest of the domestic economy, the apparent dilemma between promoting in and out-group interests seem to be an issue for residents. It is important to investigate this dilemma and its consequences further, and we urge further research on this topic.

Our results also shed light on two contingency factors that strengthen and respectively weaken the positive effect TE exerts on the dependent variables. The more a tourist believes that his or her own travel behavior can make a difference, the stronger the positive effect of TE on willingness to engage in domestic tourism. Importantly, this interaction effect is not present for the other three TRO. This result bears the important insight that even individuals who don't consider themselves capable of contributing directly to the domestic tourism economy, still engage in indirectly supportive behavior (i.e. WOM and RST) as much as those high on efficacy. As for the second interaction variable, residents' perceived support from others, we find that the more residents perceive others to already contribute to the domestic tourism economy, the weaker is the effect of TE on all four dependent variables. This result confirms findings in the social psychology literature where perceptions of other people's support is used by individual group-members as justification for contributing less to the group's goal (Latane and Nida 1981). In addition, we found that if a resident perceives a 
lack of support from others, he or she overcomes the in-group bias and exerts it to the outgroup, thereby showing increased hospitability to incoming tourists. This result documents that TE can indeed drive residents' hospitability toward incoming tourists, but only if an urgent lack of support from fellow in-group members is present. While being relevant for tourism researchers, this new finding is also of importance for social psychologists because it advances our understanding of the conditions under which an in-group bias may spill over to an out-group bias. 


\section{Conclusion}

In recent years, patriotic sentiments in the public and among politicians have become increasingly prominent, with consequences for the economy, societies and the political landscape. Research on ethnocentrism is relatively advanced in the politics, psychology and marketing domains, yet there has been little mention let alone substantial investigation of this phenomenon in tourism. The present research provides a timely contribution to our understanding of how a home country bias among both tourists and residents influences their behavior in the tourism domain. This study represents the first investigation of the role of tourism ethnocentrism for tourists and residents. Inspired by substantive findings in social psychology literature, the study reported here identifies, conceptualizes and empirically validates the construct of tourism ethnocentrism as an important motive behind tourists' and residents' predispositions toward the domestic destination.

A fundamental contribution to tourism research is that TE is important to include in future studies that set out to investigate tourists' travel intentions or residents' attitudes toward domestic tourism development. As for the tourist domain, we show that TE exerts an independent effect on tourists' travel predispositions and complements the established literature on mental destination representations (e.g., destination image and destination imagery) in explaining tourist behavior. In this regard TE adds and can continue to contribute to the growing literature on symbolic reasons for tourists' destination selection (e.g., Boley et al. 2018, Ekinci and Hosany 2006; Sirgy and Su 2000). The newly developed TE construct also adds value to the research on residents' predispositions toward and support of tourism (Perdue et al. 1990; Sharpley 2014; Stylidis et al. 2014; Woo et al. 2015). We identify TE as a new and promising intrinsic variable that can explain residents' support for domestic tourism development. 
We put forward that TE may serve as a silver bullet for tourism managers because it has important effects on individuals' predispositions both in their role as tourists and residents. Importantly, the TE bias is not related to perceptions about the quality of a destination but motivates individuals to prefer domestic destinations for other reasons than quality, affording domestic tourism stakeholders a competitive advantage and making it hard for foreign destinations to compete for the tourists that score high on TE. Furthermore, appealing to ethnocentric individuals may even attract tourists with more positive evaluations of foreign than domestic destinations to holiday domestically. Specifically, the effect of TE is able to overrule the 'normal' route from evaluation, to intention and behavior. In this way, a TE bias may overrule quality considerations, which might have resulted in a different tourist decision. Understanding and actively managing TE may therefore be a key success factor for a domestic destination that faces ever-increasing competition from foreign alternatives. TE is both a barrier for foreign destinations and an advantage for domestic ones. Foreign destination managers have to be aware that, in spite of low explicit travel barriers (e.g. visa applications), TE still exists as an intangible barrier in the minds of tourists, and is hard to overcome with traditional marketing approaches. Interestingly and somewhat counterintuitively, current political and societal trends indicate that increasing levels of globalization may fuel, rather than decrease, this predisposition.

Domestic destination managers may also benefit from ethnocentric predispositions by communicating a native or local imagery of their tourism products. Importantly, even small tourism companies can easily adopt this approach. Domestic companies could take advantage of the TE effect by investigating TE levels in their market, and if levels are high, the use of possessing and communicating a local image could be highly effective. If TE levels are low, then options are to either not apply a local image strategy or to attempt to influence the target market to include TE more prominently as a decision variable by articulating the benefits of 
supporting the domestic economy. If TE levels are high, the current net export rate (i.e. export larger than import) of the U.S. can be further increased, while for a country that has a net import rate, such as Germany, TE can contribute to alleviating this gap (NTTO 2017). While not explicitly tested in this research, it is likely that TE also influences preferences for accommodation owned by domestic firms rather than by foreign or multinational chains. As such, communicating a local image may be a feasible strategy for small hotels to hold multinational hotel companies at bay.

We urge researchers to investigate how home country biases impact tourists' intentions to travel abroad, specifically in the case of popular international destinations. It is of interest to learn whether TE affects intentions to visit even highly popular international destinations. Further, in order to understand and manage TE more effectively, insight into potential conditions that affect the impact of TE on tourism-related outcomes is valuable. It would therefore be interesting to examine other contingency factors than the ones covered in this study, especially those that draw on the potential constraints that TE implies. For example, domestic holidays might not be able to cater to the travel motives of tourists strongly influenced by novelty seeking. It would also be of interest to investigate whether such factors influence the impact of TE on TRO. Another interesting research opportunity relates to applying TE to destination levels other than countries, such as the levels of states, subnational or supernational regions. Finally, we have investigated a positive in-group bias that enhances understanding on how tourists and residents make favorable decisions about their domestic destination. We urge future studies to build on this and investigate negative biases and their potential impact on tourists' and residents' behavior.

We also found that tourists are more likely to act on their tourism ethnocentric tendencies when they perceive that they make a difference and when they perceive that others are not doing enough to help the domestic tourism economy. The implication for tourism marketers is 
that it is in the interest of domestic tourism stakeholders to communicate the value of the actions of each individual inhabitant both as a tourist and as a resident, for example, through the launch of a campaign that highlights the benefits of domestic tourism. It is important that the domestic inhabitants know that they make a difference. Moreover, failing to understand TE in the target market can have significant bottom-line implications in other ways. When Walt Disney World in Orlando laid off a large number of American employees and substituted them with immigrants, one laid-off employee described the ordeal in this manner: "They [Disney] are just doing things to save a buck, and it's making Americans poor" (Preston 2016). Overall, tourism ethnocentrism is an important phenomenon to understand for tourism researchers and managers, and provides rich opportunities for future research given the potential insight for tourism theory and practice. 


\section{References}

Ajzen, I. 2001. "Nature and Operation of Attitudes.” Annual Review of Psychology 52.1 (2001): 27-58.

Allport, G. W. 1954. The Nature of Prejudice Cambridge, MA: Addison-Wesley.

Andereck, K. L., Valentine, K. M., M. Anshell, R. C. Knopf, and C. A. Vogt. 2005.

“Residents’ Perceptions of Community Tourism Impacts.” Annals of Tourism Research 32 (4): 1056-076.

Ariffin, A. A. M. 2013. “Generic Dimensionality of Hospitality in the Hotel Industry: A Host-guest Relationship Perspective.” International Journal of Hospitality Management 35: 171-79.

Bagozzi, R. P., and Y. Yi. 1988. "On the Evaluation of Structural Equation Models.” Journal of the Academy of Marketing Science 16 (1): 74-94.

Balliet, D., J. Wu, and C. K. W. De Dreu. 2014. “Ingroup Favoritism in Cooperation: A MetaAnalysis.” Psychological Bulletin 140 (6): 1556-581.

Baloglu, S., and K. W. McCleary. 1999. “A Model of Destination Image Formation.” Annals of Tourism Research 26 (4): 868-97.

Boley, B., E. Jordan, C. Kline, and W. Knollenberg. 2018. "Social Return and Intent to Travel.” Tourism Management 64, 119-28.

Boley, B. B., and M. Strzelecka. 2016. "Towards a Universal Measure of "Support for Tourism.” Annals of Tourism Research 61: 238-41.

Brewer, M. B. 1999. “The Psychology of Prejudice: Ingroup Love and Outgroup Hate?” Journal of Social Issues 55 (3), 429-44. 
Churchill Jr, G. A. 1979. “A Paradigm for Developing Better Measures of Marketing Constructs.” Journal of Marketing Research 16(February) 64-73.

Crowne, D. P. and D. Marlowe. 1960. “A New Scale of Social Desirability Independent of Psychopathology.” Journal of Consulting Psychology 24 (3): 349-54.

Ekinci, Y., and S, Hosany. 2006. "Destination Personality: An Application of Brand Personality to Tourism Destinations. Journal of Travel Research 45 (2): 127-39.

Fornell, C., and D. F. Larcker. 1981. "Evaluating Structural Equation Models with Unobservable Variables and Measurement Error.” Journal of Marketing Research 18 (February): 39-50.

Gilgun, J. F. 2005. “Deductive Qualitative Analysis and Family Theory Building.” In Sourcebook of Family Theory and Research, edited by V. Bengtson, A. Acock, K. Allen, P. Dilworth-Anderson, and D. Klein, 83-84. Thousand Oaks, CA: Sage.

Hair, J., R. Anderson, R. Tatham, and W. Black. 1998. Multivariate Data Analysis, 5th Ed. Upper Saddle River, NJ: Prentice Hall.

Hammond, R. A., and R. Axelrod. 2006. “The Evolution of Ethnocentrism.” Journal of Conflict Resolution 50 (6): 926-36.

Heider, F. 1958. „The Psychology of Interpersonal Relations. New York: John Wiley \& Sons.

Henseler, J., C. M. Ringle, and M. Sarstedt. 2015. “A New Criterion for Assessing Discriminant Validity in Variance-based Structural Equation Modeling." Journal of the Academy of Marketing Science 43 (1): 115-35.

Hewstone, M., M. Rubin, and H. Willis. 2002. "Intergroup bias.” Annual Review of Psychology 53 (1): 575-604. 
Homburg, C. M. Schwemmle, and C. Kuehnl. 2015. "New Product Design: Concept, Measurement, and Consequences.” Journal of Marketing 79(3), 41-56.

John, A., and J. G. Klein. 2003. “The Boycott Puzzle: Consumer Motivations for Purchase Sacrifice.” Management Science 49 (9): 1196-209.

Josiassen, A. 2011. “Consumer Disidentification and Its Effects on Domestic Product Purchases: An Empirical Investigation in the Netherlands.” Journal of Marketing 75 (March): 124-40.

Josiassen, A., A. G. Assaf, and I. O. Karpen. 2011. "Consumer Ethnocentrism and Willingness to Buy.” International Marketing Review, 28 (6): 627-46.

Josiassen, A., A. G. Assaf, L. Woo, and F. Kock. 2016. “The Imagery-Image Duality Model: An Integrative Review and Advocating for Improved Delimitation of Concepts." Journal of Travel Research 55 (6): 789-803.

Klein, J. G., R. Ettenson, R., and M. D. Morris. 1998. “The Animosity Model of Foreign Product Purchase: An Empirical Test in the People's Republic of China.” Journal of Marketing 62 (1): 89-100.

Klein, J. G., N. C. Smith, and A. John. 2004. "Why we Boycott: Consumer Motivations for Boycott Participation.” Journal of Marketing 68 (3): 92-109.

Kline, R. B. 2011. Principles and Practice of Structural Equation Modeling. New York: Guilford Press.

Kock, F., A. Josiassen, and A. G. Assaf. 2016. “Advancing Destination Image: The Destination Content Model.” Annals of Tourism Research 61: 28-44.

Latane, B., and S. Nida. 1981. "Ten Years of Research on Group Size and Helping." Psychological Bulletin 89 (2): 308-24. 
Lowery, B. S., M. M. Unzueta, E. D. Knowles, and P. A. Goff. 2006. “Concern for the Ingroup and Opposition to Affirmative Action.” Journal of Personality and Social Psychology 90 (6): $961-74$.

Lovett, M. J., R. Peres, and R. Shachar. 2013. “On Brands and Word of Mouth.” Journal of Marketing Research, 50 (November): 427-44.

NTTO: National Travel \& Tourism Office. 2017. "National Travel and Tourism Balance U.S. 2016."https://travel.trade.gov/outreachpages/download_data_table/2016\%20Travel\%20Expor t\%20\&\%20Import\%20Country\%20Estimates.pdf.

Ouellet, Jean. 2007. "Consumer Racism and Its Effects on Domestic Cross-Ethnic Product Purchase: An Empirical Test in the United States, Canada, and France.” Journal of Marketing 71 (January): 113-28.

Pearce, P. L., and P. F. Stringer. 1991. "Psychology and Tourism.” Annals of Tourism Research 18: 136-54.

Perdue, R, R., P. T. Long, and L. Allen. 1990. "Resident Support for Tourism Development.” Annals of Tourism Research 17 (4): 586-99.

Peter, J. P. 1981. “Construct Validity: A Review of Basic Issues and Marketing Practices.” Journal of Marketing Research 18 (2): 133-45.

Petter, S., D. Straub, and A. Rai. 2007. "Specifying Formative Constructs in Information Systems Research.” MIS Quarterly 31 (4): 623-56.

Prayag, G., \& C. Ryan, C. 2012. “Antecedents of Tourists' Loyalty to Mauritius: The Role and Influence of Destination Image, Place Attachment, Personal Involvement, and Satisfaction.” Journal of Travel Research, 51(3), 342-56. 
Preston, J. 2016. “Lawsuit claims Disney Colluded to replace us Workers with Immigrants.” New York Times, January 25. https://www.nytimes.com/2016/01/26/us/lawsuit-claims$\underline{\text { disney-colluded-to-replace-us-workers-with-immigrants.html. }}$

Schaller, M., and S. L. Neuberg. 2008. "Intergroup prejudices and intergroup conflicts.” In Foundations of Evolutionary Psychology: Ideas, Issues, and Applications, edited by C.

Crawford and D. L. Krebs, 399-412. Mahwah, NJ: Erlbaum.

Sirgy, M. J., C. Su. 2000. Destination Image, Self-Congruity, and Travel Behavior: Toward an Integrative Model. Journal of Travel Research 38 (4): 340-52.

Rasoolimanesh, S. M., Roldán, J. L., Jaafar, M., and T. Ramayah. 2017. “Factors Influencing Residents' Perceptions toward Tourism Development: Differences across Rural and Urban World Heritage Sites.” Journal of Travel Research 56 (6):760-75.

Scheepers, D., R. Spears, B. Doosje, and A. S. R. Manstead. 2006. "Diversity in In-group Bias: Structural Factors, Situational Features, and Social Functions.” Journal of Personality and Social Psychology 90 (6): 944-60.

Shankarhamesh, M. N. 2006. "Consumer Ethnocentrism: An Integrative Review of its Antecedents and Consequences.” International Marketing Review 28 (6): 627 - 46.

Sharpley, R. 2014. "Host Perceptions of Tourism: A Review of the Research.” Tourism Management 42: 37-49.

Sherif, M., C. W.Sherif. 1953. Groups in Harmony and Tension. New York: Harper.

Sumner, G. A. 1906. Folkways. New York: Ginn Custom Publishing.

Shimp, T. A., and S. Sharma. 1987. "Consumer Ethnocentrism: Construction and Validation of the CETSCALE.” Journal of Marketing Research 24 (3): 280-89. 
Stylidis, D., A. Biran, J. Sit, and E. M. Szivas. 2014. 'Residents' Support for Tourism Development: The Role of Residents' Place Image and Perceived Tourism Impacts.” Tourism Management, 45: 260-74.

Tajfel, H. 1982. "Social Psychology of Intergroup Relations.” Annual Review of Psychology 33 (1): 1-39.

Teye, V., E. Sirakaya, and S. F. Sönmez. 2002. “Residents' Attitudes toward Tourism Development.” Annals of Tourism Research 29 (3): 668-88.

The Economist. 2017. "Trump on Trumponomics: Nationalism plus Flexibility.” Print Edition, November $19^{\text {th }}$.

The Economist. 2016. “The New Nationalism.” Print Edition, May $11^{\text {th }}$.

UNWTO - United Nations World Tourism Organization. 2017. "UNWTO Tourism Highlights 2017.” https://www.e-unwto.org/doi/pdf/10.18111/9789284419029.

Vargas-Sánchez, A., N. Porras-Bueno, and M. A. Plaza-Mejía. "Explaining Residents' Attitudes to Tourism: Is a Universal Model Possible?” Annals of Tourism Research 38 (2): 460-80.

Verlegh, P. W. J. 2007. "Home Country Bias in Product Evaluation: The Complementary Roles of Economic and Socio-Psychological Motives." Journal of International Business Studies 38 (3): 361-73.

Voss, K. E., E. R. Spangenberg, and B. Grohmann. 2003. "Measuring the Hedonic and Utilitarian Dimensions of Consumer Attitude.” Journal of Marketing Research 40 (3): 310-20.

Walsh, G., H. Evanschitzky, H., and M. Wunderlich. 2008. "Identification and Analysis of Moderator Variables: Investigating the Customer satisfaction-loyalty Link.” European Journal of Marketing, 42 (9/10), 977-1004. 
Wilson, S., D. R. Fesenmaier, J. Fesenmaier, and J. C. Van Es. 2001. "Factors for Success in Rural Tourism Development.” Journal of Travel Research, 40 (2): 132-38.

Woo, E., H. Kim, and M. Uysal. 2015. "Life Satisfaction and Support for Tourism Development.” Annals of Tourism Research 50: 84-97.

Woosnam, K. M., W. C. Norman, and T. Ying. 2009. "Exploring the Theoretical Framework of Emotional Solidarity between Residents and Tourists." Journal of Travel Research 48 (2): $245-58$. 


\section{Tables}

Table 1: Statements yielded by the interviews

\begin{tabular}{|c|}
\hline Exemplary statements \\
\hline $\begin{array}{l}\text { "I spend my holiday here in America in order to support Americans } \\
\text { who work in the tourism industry." (R3) }\end{array}$ \\
\hline $\begin{array}{l}\text { "Tourism is a big business, whole cities and millions of people in the } \\
\text { US depend on it. Our duty is to support them." (R8) }\end{array}$ \\
\hline $\begin{array}{l}\text { "If I spend my holiday here in the US, the money will stay here and } \\
\text { create new jobs, everybody benefits, it's that simple." (R12) }\end{array}$ \\
\hline $\begin{array}{l}\text { "Vacationing abroad only makes other countries richer. These people } \\
\text { don't come to the US, so why should we go and leave our money } \\
\text { there?" (R13) }\end{array}$ \\
\hline $\begin{array}{l}\text { "I support our local tourism, it comes down to all of us to make } \\
\text { America great again." (R16) }\end{array}$ \\
\hline $\begin{array}{l}\text { "I don't travel to Canada for vacation, I earn my money here and I } \\
\text { spend my money here. We Americans gotta stick together." (R6) }\end{array}$ \\
\hline
\end{tabular}


Table 2: Parameters of the TE scale

\begin{tabular}{|c|c|c|c|c|}
\hline Constructs/Items & $\begin{array}{l}\text { Item } \\
\text { Mean }\end{array}$ & $\begin{array}{c}\text { Item } \\
\text { Loadings }\end{array}$ & $\begin{array}{c}\text { Corrected Item-to- } \\
\text { Total Correlation }\end{array}$ & $\begin{array}{c}\text { Scale } \\
\text { parameters }\end{array}$ \\
\hline $\begin{array}{l}\text { 1. Americans should support the } \\
\text { American economy by travelling } \\
\text { to holiday destinations in the } \\
\text { US. }\end{array}$ & 4.78 & .73 & .71 & \\
\hline $\begin{array}{l}\text { 2. Americans should feel a duty } \\
\text { to book a national holiday. }\end{array}$ & 3.70 & .83 & .79 & \\
\hline $\begin{array}{l}\text { 3. Everyone should support the } \\
\text { American economy by spending } \\
\text { their holiday in the US. }\end{array}$ & 4.00 & .91 & .87 & \\
\hline $\begin{array}{l}\text { 4. Every time an American } \\
\text { decides to spend their holiday in } \\
\text { the US, it makes America's } \\
\text { future a little bit brighter. }\end{array}$ & 4.45 & .78 & .76 & \\
\hline $\begin{array}{l}\text { 5. It comes down to all } \\
\text { Americans to spend their } \\
\text { holiday in the US and support } \\
\text { the country. }\end{array}$ & 3.79 & .87 & .81 & \\
\hline $\begin{array}{l}\text { 6. Americans should spend their } \\
\text { holiday in the US because this } \\
\text { secures jobs in the American } \\
\text { tourism industry. }\end{array}$ & 4.21 & .86 & .83 & \\
\hline Composite reliability (CR) & & & & .94 \\
\hline $\begin{array}{l}\text { Average Variance Extracted } \\
\text { (AVE) }\end{array}$ & & & & .74 \\
\hline $\begin{array}{l}\text { Explained variation of extracted } \\
\text { factor }\end{array}$ & & & & .68 \\
\hline
\end{tabular}

Notes: The items are scored on a seven-point Likert scale $(1=$ "strongly disagree," and 7 = "strongly agree"). 
Table 3: Constructs used in the TE framework

\begin{tabular}{|c|c|c|c|}
\hline Construct/Items & Factor Loadings & $\mathbf{C R}$ & AVE \\
\hline Tourism ethnocentrism (newly developed) & & .94 & .72 \\
\hline 1. Americans should support the American economy by travelling to holiday destinations in the US. & .76 & & \\
\hline 2. Americans should feel a duty to book a national holiday. & .71 & & \\
\hline 3. Everyone should back up the American economy by spending their holiday in the US. & .87 & & \\
\hline 4. Every time an American decides to spend their holiday in the US, it makes America's future a little bit brighter. & .84 & & \\
\hline 5. It comes down to all Americans to spend their holiday in the US and support the country. & .86 & & \\
\hline 6. Americans should spend their holiday in the US because this secures jobs in the American tourism industry. & .85 & & \\
\hline Willingness to visit (Kock et al. 2016) & & .95 & .87 \\
\hline 1. I intend to spend my next holiday at a destination in the US. & .89 & & \\
\hline 2. The next time I go on vacation, I will choose a domestic destination. & .92 & & \\
\hline 3. It is very likely that I would choose the US as my tourist destination. & .88 & & \\
\hline Positive word of mouth (Kock et al. 2016) & & .95 & .85 \\
\hline 1. I talk up the US as a holiday destination to people I know. & .82 & & \\
\hline 2. I bring up the US in a positive way in conversations about holiday destinations. & .93 & & \\
\hline 3. I n social situations, I often speak favorably about the US as a tourist destination. & .90 & & \\
\hline Residents hospitality (newly developed) & & .93 & .78 \\
\hline 1. I try to be helpful if a tourist asks me for help. &, 81 & & \\
\hline 2. I happily interact with tourists. & ,90 & & \\
\hline 3. If I have the opportunity, I am hospitable toward tourists. &, 85 & & \\
\hline
\end{tabular}




\begin{tabular}{|c|c|c|c|}
\hline 4. I would do my bit to make the US a welcoming country for tourists. & ,80 & & \\
\hline Residents' support for tourism development (adapted from Stylidis et al. 2014; Woo et al. 2015) & & .90 & .74 \\
\hline 1. I support tourism development in our country. & ,79 & & \\
\hline 2. I am supportive of increasing tourism in our country. & ,89 & & \\
\hline 3. The money invested to attract more tourists to our country is a good investment. & ,68 & & \\
\hline \multicolumn{4}{|l|}{ Perceived tourist self-efficacy (adapted from Klein et al. 2004) } \\
\hline 1. I do not travel enough to make a difference for the American tourism industry. & - & - & - \\
\hline \multicolumn{4}{|l|}{ Perceived support of fellow tourists (adapted from Klein et al. 2004) } \\
\hline 1. Enough Americans support the domestic tourism industry. & - & - & - \\
\hline Consumer Ethnocentrism (Shimp and Sharma 1987) & & .93 & .69 \\
\hline 1. Foreigners should not be allowed to put their products on our markets. & .74 & & \\
\hline 2. Purchasing foreign-made products is un-American. & .84 & & \\
\hline 3. We should buy from foreign countries only those products that we cannot obtain within our own country. & .76 & & \\
\hline 4. Curbs should be put on all imports & .80 & & \\
\hline 5. It is not right to purchase foreign products, because it puts American people out of jobs. & .86 & & \\
\hline 6. We should purchase products manufactured in the US instead of letting other countries get rich off of us. & .77 & & \\
\hline
\end{tabular}


Table 4: Path coefficients in the four structural models yielded by median splits

\begin{tabular}{|l|c|c|c|c|c|c|}
\hline & $\begin{array}{c}\text { Low } \\
\text { perceived } \\
\text { self-efficacy }\end{array}$ & $\begin{array}{c}\text { High } \\
\text { perceived } \\
\text { self-efficacy }\end{array}$ & $\begin{array}{c}\chi^{2} \text {-square } \\
\text { difference } \\
\text { test }\end{array}$ & $\begin{array}{c}\text { Low } \\
\text { perceived } \\
\text { support }\end{array}$ & $\begin{array}{c}\text { High } \\
\text { perceived } \\
\text { support }\end{array}$ & $\begin{array}{c}\chi^{2} \text {-square } \\
\text { difference } \\
\text { test }\end{array}$ \\
\hline TE $\rightarrow$ & $.305 * * *$ & $.489 * * *$ & $* *$ & $.591 * * *$ & $.333 * * *$ & $* *$ \\
WTV & & & & & & \\
\hline TE $\rightarrow$ \\
WOM
\end{tabular}

Notes: $\mathrm{ns}=$ not significant $, * \mathrm{p}<.10, * * \mathrm{p}<.05, * * * \mathrm{p}<.01$. 


\section{Figures}

Figure 1: The TE framework: Structural equation modelling results

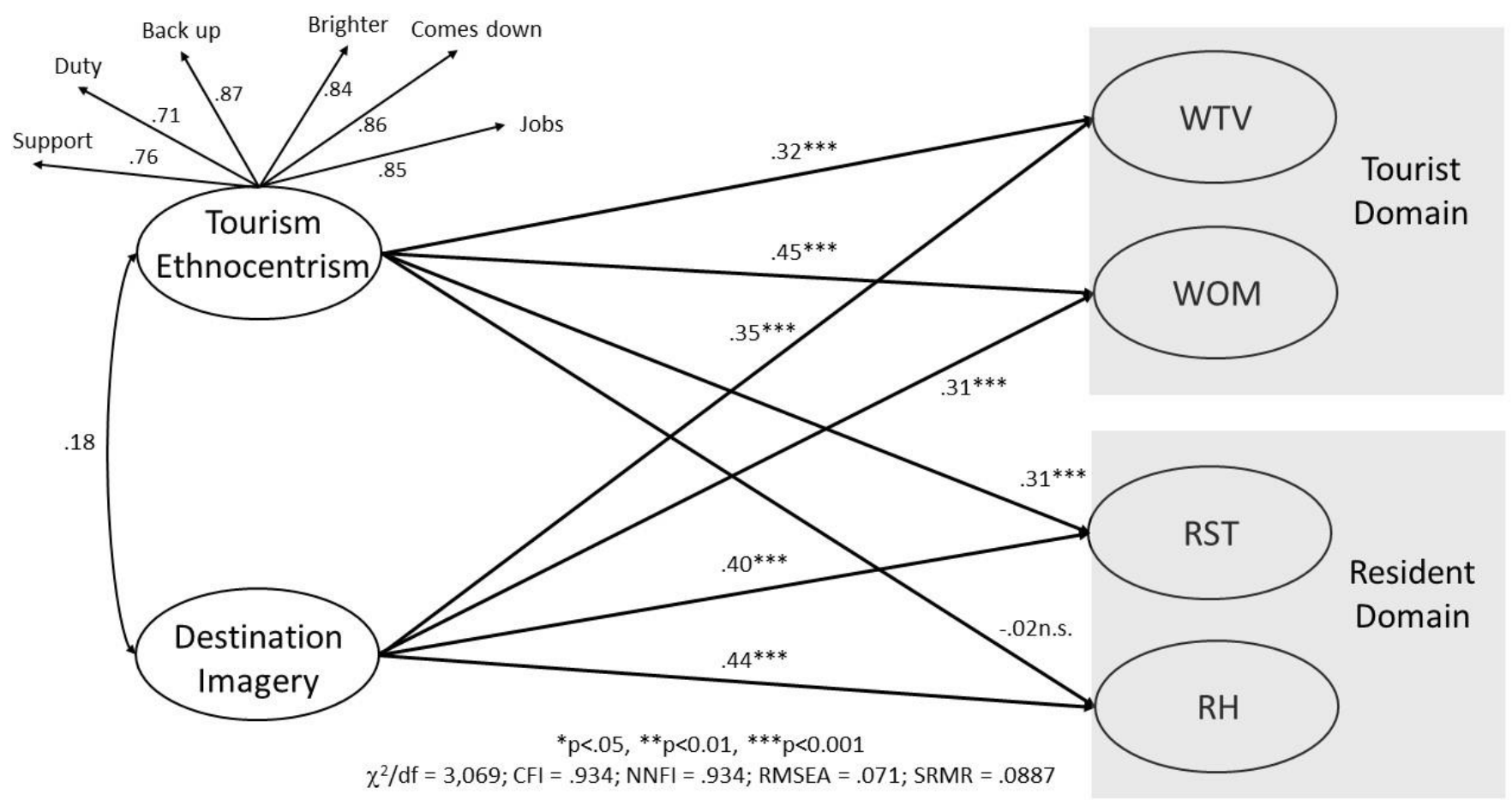

